\title{
POLYMORPHISM OF PROINFLAMMATORY CYTOKINE GENES IN GIRLS PREDISPOSED TO RECURRENT RESPIRATORY INFECTIONS
}

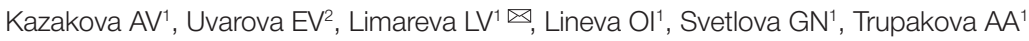 \\ ${ }^{1}$ Samara State Medical University, Samara \\ ${ }^{2}$ Kulakov National Medical Research Center for Obstetrics, Gynecology, and Perinatology, Moscow
}

Acute respiratory infections (ARI) are very common in children and often prompt parents to seek medical advice. Increased susceptibility to ARI is caused by a number of factors, including genetically determined imbalances in cytokine production. The aim of this study was to analyze the frequency of 6 clinically relevant polymorphisms of proinflammatory cytokine genes in girls predisposed to recurrent respiratory infections. The study was conducted in girls aged 7-17 years who were undergoing a routine medical checkup. A group of children with frequent respiratory infections was identified. The following polymorphisms were analyzed for possible associations with predisposition to frequent respiratory infections: IL1 3 T-31C (rs 1143627 ), IL1 $\beta$ T-511C

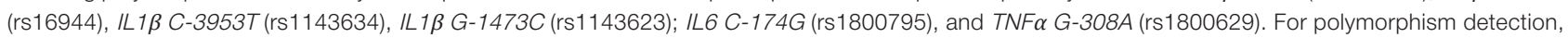
PCR and gel electrophoresis were used. The following alleles were found to be associated with an increased risk for recurrent respiratory infections in girls aged 7-17 years: C-31 (rs1143627) $(\mathrm{OR}=2.05 ; \mathrm{Cl}: 1.16-3.64 ; p=0.013)$ and $C-511$ ( $\mathrm{rs} 16944)(\mathrm{OR}=3.11 ; \mathrm{Cl}: 1.25-7.76 ; p=0.013)$ of the $\mathrm{IL}-1 \beta$ gene.

Keywords: recurrent respiratory infections in children, pro-inflammatory cytokines, gene polymorphism

Author contribution: Kazakova AV — conception and design of the study; data acquisition and statistical analysis; Uvarova EV — conception and design of the study; manuscript preparation; Limareva LV — conception and design of the study; statistical analysis; manuscript preparation; Trupakova AA — data acquisition; Svetlova GN, Lineva OI — manuscript preparation.

Compliance with ethical standards: the study was approved by the Ethics Committee of Samara State Medical University (Protocol № 5 dated April 20, 2018). Informed consent was obtained from the parents.

$\triangle$ Correspondence should be addressed: Larisa V. Limareva Gagarina, 20, Samara, 443079; larisa-limareva@yandex.ru

Received: 02.12.2019 Accepted: 18.12.2019 Published online: 25.12.2019

DOI: 10.24075/brsmu.2019.087

\section{ОСОБЕННОСТИ ПОЛИМОРФИЗМА ГЕНОВ ПРОВОСПАЛИТЕЛЬНЫХ ЦИТОКИНОВ У ДЕВОЧЕК, ПРЕДРАСПОЛОЖЕННЫХ К ЧАСТЫМ РЕСПИРАТОРНЫМ ЗАБОЛЕВАНИЯМ}

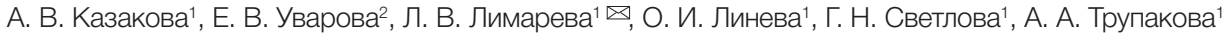

${ }^{1}$ Самарский государственный медицинский университет, Самара, Россия

2 Национальный медицинский исследовательский центр акушерства, гинекологии и перинатологии имени академика В. И. Кулакова, Москва, Россия

Респираторные заболевания (ОРЗ) относят к числу наиболее распространенных заболеваний детского возраста и служат поводом частого обращения за медицинской помощью. Повышенная заболеваемость детей определяется целым рядом факторов, в том числе наличием дисбаланса в системе цитокинов, уровень синтеза которых генетически детерминирован. Целью работы было проанализировать особенности распределения шести клинически значимых полиморфных локусов в генах провоспалительных цитокинов у девочек с частыми респираторными заболеваниями. Среди девочек 7-17 лет, проходящих плановый профилактический осмотр, на основании анамнеза была выделена группа часто болеющих детей

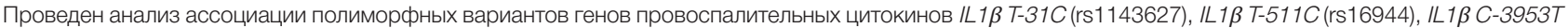

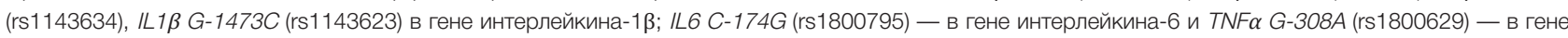
фактора некроза опухоли альфа с предрасположенностью к частым респираторным заболеваниям. Полиморфные варианты генов выявляли методом ПЦР с электрофоретической детекцией. Показано, что с повышенным риском рецидивирующих респираторных заболеваний у девочек 7-17 лет

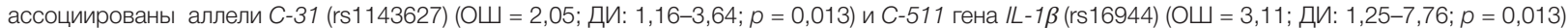

Ключевые слова: часто болеющие дети, провоспалительные цитокины, полиморфизм генов

Информация о вкладе авторов: А. В. Казакова - концепция и дизайн исследования, сбор и обработка материала, статобработка, написание и редактирование текста; Е. В. Уварова - концепция и дизайн исследования, редактирование текста; Л. В. Лимарева - концепция и дизайн исследования, статобработка, написание и редактирование текста; А. А. Трупакова - сбор и обработка материала; Г. Н. Светлова, О. И. Линева написание текста.

Соблюдение этических стандартов: исследование одобрено этическим комитетом СамГМУ (протокол № 5 от 20 апреля 2018 г.). Родителями участников исследования были подписаны добровольные информированные согласия на участие в исследовании и публикацию результатов.

$\triangle$ Для корреспонденции: Лариса Владимировна Лимарева

ул. Гагарина, д. 20, г. Самара, 443079; larisa-limareva@yandex.ru

Статья получена: 02.12.2019 Статья принята к печати: 18.12.2019 Опубликована онлайн: 25.12.2019

DOI: $10.24075 /$ vrgmu.2019.087

To date, it has been convincingly demonstrated that the immune system plays a critical role in disease progression. In both health and pathology, immune response is regulated by cytokines, the key mediators of cell-cell interactions in the immune system [1, 2]. An imbalance between pro- and anti-inflammatory cytokines compromises immune defense against infection and leads to chronicity [3]. The intensity of cytokine secretion depends on the expression of cytokine-encoding genes, which, in turn, is determined by the presence of persistent microorganisms and genetic features of the host [4]. Single nucleotide polymorphisms (SNPs) of human genes coding for immunocompetent molecules determine the level of cytokine production in response to infection, affecting the clinical course of the disease [5-7]. So far, a number of polymorphic loci have been identified in promotor regions of the genes involved in the production of proinflammatory cytokines (IL1 $\beta$, IL6, TNF $\alpha$, etc.) [8-12].

Acute respiratory infections (ARI) are very common in childhood. A child falls in the "frequently ill" category if he/she 
has more than 6 episodes of ARI a year; this definition refers to repeated or recurrent viral, bacterial or mixed infections of ear, nose and throat (adenoiditis, tonsillitis, otitis), upper (laryngitis) or lower respiratory tract (tracheitis, bronchitis, pneumonia) developing as a result of compromised immunity or inadequate therapy for ARI [13-15]. Increased susceptibility to ARI is determined by a few factors, including genetic ones. There is an ongoing search for possible immunogenetic markers of such predisposition.

The aim of our study was to explore possible associations between the polymorphisms of genes coding for key proinflammatory cytokines and predisposition to frequent respiratory infections in girls aged 7 to 17 years.

\section{METHODS}

We examined 116 girls aged 7 to 17 years residing in Samara who visited a pediatric/adolescent gynecologist for a routine checkup in 2014-2016. The following inclusion criteria were applied: age between 7 and 17 years; the absence of severe organic pathology; normal physical, sexual and cognitive development. Exclusion criteria: age outside the specified range; severe organic pathology; developmental abnormalities. We analyzed the medical history of the patients (frequency of respiratory infections and their course) and allele and genotype frequencies for proinflammatory cytokine genes using PCR with gel electrophoresis (SNP-EXPRESS assay; Litech; Russia). We searched for the following SNPs: IL1 $\beta$ T-31C (rs1143627), IL1 $\beta$ T-511C (rs16944), IL1 $\beta$ C-3953T (rs1143634), IL1 $\beta$ G-1473C (rs1143623); IL6 C-174G (rs1800795), and TNF $\alpha$ G-308A (rs1800629). DNA was isolated from the buccal mucosa using an express DNA isolation kit (Litech; Russia). SNPs selected for our study are associated with human immune status and were proposed as clinically and diagnostically relevant at the 15th International Histocompatibility and Immunogenetics Workshop in Brazil in 2008 [16].

DNA was amplified in a DTlite-4S1 thermocycler (DNATechnology; Russia). The observed genotype frequencies were tested for conformity to Hardy-Weinberg expectations using Pearson's $\chi^{2}$. We measured possible associations and assessed the significance of differences in the distribution of categorical variables (odds ratios and 95\% confidence intervals). Statistical analysis was performed online on the website of the Institute of Human Genetics (Munich, Germany) using DeFinetti software [17]. The minor alleles were hypothesized to be risk alleles and were analyzed in all combinations.

\section{RESULTS}

The analysis of clinical data and medical histories revealed that $56.9 \%$ of the participants had ARI 6 to 10 times a year. Of them, $10.6 \%$ had a chronic ENT pathology (tonsillitis, pharyngolaryngitis) with frequent relapses (4 to 6 times a year) in the setting of acute viral and/or bacterial infection. The girls were divided into 2 groups: 65 girls constituted the group of children with recurrent respiratory infections and 51 girls made up the group without recurrent ARI.

The genotype frequency of 5 out of 6 analyzed SNPs conformed to the Hardy-Weinberg equilibrium. The only exception was TNF $\alpha$ (G-308A); therefore, this polymorphism was excluded from further analysis (see Table).

The analysis of allele/genotype frequencies of the genes encoding proinflammatory cytokines demonstrated that the general sample was dominated by the carriers of the alleles $T-31$, G-1473 and $C$-3953 in the $I L 1 \beta$ gene $(p<0.05)$ determining the high levels of the encoded cytokines. In the case of $I L 1 \beta$ (T-511C) and IL6 (C-174G), the alleles associated with high and low levels of $I L 1 \beta$ and $I L 6$ were distributed in our sample relatively equally.

Comparison of individual polymorphisms occurring at the clinically relevant loci of the studied cytokine genes and associated with high/low levels of their expression revealed that homozygous and heterozygous $C$ alleles at positions 31 and 511 of the $I L 1 \beta$ gene were significantly more frequent in the group of girls suffering from recurrent infections. The presence of the C-31 allele increased the risk of frequent respiratory infections twofold $(\mathrm{OR}=2.05$; $\mathrm{Cl}$ : 1.16-3.64) in comparison with the T-31 allele. The highest risk of recurrent infections was detected in the carriers of the CC genotype in comparison with heterozygous CT carriers (OR $=2.58$; $\mathrm{Cl}$ : $1.14-5.85)$ and the pooled $C T$ and $T T$ genotypes $(\mathrm{OR}=2.65 ; \mathrm{Cl}$ : 1.25-5.63). The presence of any $C-511$ allele variant also indicated a high risk of recurrent respiratory infections $(\mathrm{OR}=1.68$; $\mathrm{Cl}$ : 0.99-2.83; $p=0.053)$. The risk of frequent respiratory infections increased more than threefold in the carriers homozygous for $C C$ in comparison with heterozygous CT $(\mathrm{OR}=3.28$; $\mathrm{Cl}$ : 1.22-8.79), homozygous $\Pi(\mathrm{OR}=2.9$; $\mathrm{Cl}$ : $1.03-8.17)$ and the pool of children with $C T$ or $\Pi T(\mathrm{OR}=3.11 ; \mathrm{Cl}: 1.25-7 / 76)$ at $-511 \mathrm{C} / \mathrm{T}$ of the $I L 1 \beta$ gene.

We failed to establish a statistically significant association between recurrent respiratory infections and the IL6 (C-174G) polymorphism, but the girls suffering from recurrent infections were homozygous for the $G$ allele associated with high levels of IL6 1.5 times as rare as the girls without recurrent respiratory infections $(\mathrm{OR}=0.57 ; \mathrm{Cl}$ : 0.20-1.59; $p=0.77)$.

\section{DISCUSSION}

Long-lasting and frequent respiratory infections, especially at early age, present a medical challenge yet unsolved, creating a serious social and economic burden for the family and the society in general. The contemporary view on the problem is that the primary causes of high susceptibility to infection in children are the immaturity of the immune system and genetic predisposition $[18,19]$. Cytokines play an important role in defense against pathogens: they regulate response to infection not only at the immune system level but also at the level of the whole organism. So far, extensive evidence has been accumulated suggesting that SNPs of cytokine genes can be functional and alter expression of the latter. Such functional polymorphisms hereditarily determine the levels of cytokine production in an individual, affecting the progression and outcome of infectious diseases and immunopathological processes [20]. Anti-inflammatory cytokines play a central role in the formation and regulation of inflammatory response in both innate and adaptive immunities. Therefore, research into the polymorphisms of genes coding for key proinflammatory cytokines can result in the emergence of new diagnostic and therapeutic approaches [21, 22].

In this study, we analyzed associations between polymorphisms of genes coding for key proinflammatory cytokines and predisposition to recurrent respiratory infections in 7 to 17 -year old girls. Clinically relevant functional polymorphisms were assessed, including $I L 1 \beta(T-31 C), I L 1 \beta(T-511 C), I L 1 \beta$ (C-3953T), IL1 $\beta$ (G-1473C), IL6 (C-174G), and TNF $\alpha$ (G-308A).

In the first stage of the study, we analyzed allele/genotype frequencies of polymorphic variants of the genes encoding proinflammatory cytokines in all study participants regardless of their predisposition to frequent ARI and tested the conformity of the observed data to the Hardy-Weinberg equilibrium. This is an 
Table. Polymorphic allele and genotype frequencies for the genes encoding proinflammatory cytokines in girls aged 7 to 17 years

\begin{tabular}{|c|c|c|c|c|c|}
\hline \multirow{2}{*}{$\begin{array}{c}\text { Gene } \\
\text { polymorphism }\end{array}$} & \multirow{2}{*}{$\begin{array}{l}\text { Allele, } \\
\text { genotype }\end{array}$} & \multicolumn{4}{|c|}{ Frequency, abs / \% } \\
\hline & & $\begin{array}{l}\text { All girls } \\
n=116\end{array}$ & $\begin{array}{c}\text { Without recurrent ARI } \\
\qquad n=51\end{array}$ & $\begin{array}{l}\text { With recurrent ARI } \\
\text { OP3 } n=65\end{array}$ & $\begin{array}{l}\text { Odds ratio (Confidence interval) } \\
\text { (minor allele dominating) }\end{array}$ \\
\hline \multirow{5}{*}{$\begin{array}{l}0 \\
\frac{0}{0} \\
\frac{1}{1} \\
\frac{7}{1}\end{array}$} & $\mathrm{~T}$ & $100 / 67.0 \pm 3.3^{*}$ & $46 / 75.0 \pm 4.7$ & $54 / 60.0 \pm 4.4$ & \multirow{5}{*}{$\begin{array}{c}{[1]<->[2]^{\star *}: 2.05(1.16-3.64), \chi^{2}=6.18 . p=0.013[11]<->[12]^{\star *}} \\
2.58(1.14-5.85), \chi^{2}=5.28 . p=0.022[11]<->[22]: \\
2.84(0.87-9.28), \chi^{2}=5.28, p=0.077[11]<->[12+22]^{* *} \\
2.65(1.25-5.63), \chi^{2}=6.53, p=0.011\end{array}$} \\
\hline & C & $61 / 33.0 \pm 3.3$ & $20 / 25.0 \pm 4.7$ & $41 / 40.0 \pm 4.4$ & \\
\hline & $\pi$ & $55 / 47.4$ & $31 / 60.8$ & $24 / 36.9$ & \\
\hline & CT & $45 / 38.8$ & $15 / 29.4$ & $30 / 46.2$ & \\
\hline & CC & $16 / 13.8$ & $5 / 9.8$ & $11 / 16.9$ & \\
\hline \multirow{5}{*}{$\begin{array}{l}0 \\
\frac{1}{5} \\
\frac{1}{5} \\
\frac{0}{1} \\
\end{array}$} & $\mathrm{~T}$ & $78 / 45.0 \pm 3.4$ & $36 / 52 \pm 5.5$ & $42 / 39 \pm 4.1$ & \multirow{5}{*}{$\begin{array}{c}{[1]<->[2]: 1.68(0.99-2.83), \chi^{2}=3.74, p=0.053} \\
{[11]<->[12]^{* \star}: 3.28(1.22-8.79), \chi^{2}=5.80, p=0.016} \\
{[11]<->[22]^{* *}: 2.90(1.03-8.17), \chi^{2}=3.13, p=0.042} \\
{[11]<->[12+22]^{\star *}: 3.11(1.25-7.76), \chi^{2}=6.24, p=0.013}\end{array}$} \\
\hline & $C$ & $90 / 55.0 \pm 3.4$ & $34 / 48 \pm 5.5$ & $56 / 61 \pm 4.1$ & \\
\hline & $\pi$ & $26 / 22.4$ & $17 / 33.3$ & $9 / 13.8$ & \\
\hline & CT & $52 / 44.8$ & $19 / 37.3$ & $33 / 50.8$ & \\
\hline & CC & $38 / 32.8$ & $15 / 29.4$ & $23 / 35.4$ & \\
\hline \multirow{5}{*}{ 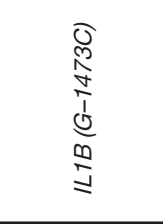 } & G & $94 / 57.0 \pm 3.3^{*}$ & $40 / 59.0 \pm 5.3$ & $54 / 55 \pm 4.1$ & \multirow{5}{*}{$\begin{array}{c}{[1]<->[2]: 1.15(0.68-1.94), \chi^{2}=0.28, p=0.600[11]<->[12]} \\
2.00(0.86-4.63), \chi^{2}=2.65, p=0.104[11]<->[22]: \\
1.11(0.39-3.18), \chi^{2}=0.04, p=0.844[11]<->[12+22]: \\
1.69(0.77-3.68), \chi^{2}=1.72, p=0.189\end{array}$} \\
\hline & C & $78 / 43.0 \pm 3.3$ & $31 / 41 \pm 5.3$ & $47 / 45 \pm 4.1$ & \\
\hline & GG & $38 / 32.7$ & $20 / 39.2$ & $18 / 27.7$ & \\
\hline & GC & $56 / 48.3$ & $20 / 39.2$ & $36 / 55.4$ & \\
\hline & CC & $22 / 19.0$ & $11 / 21.6$ & $11 / 16.9$ & \\
\hline \multirow{5}{*}{ 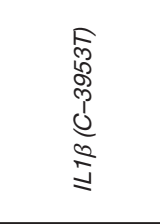 } & C & $109 / 78.0 \pm 2.8^{\star}$ & $48 / 80 \pm 4.2$ & $51 / 77.0 \pm 3.8$ & \multirow{5}{*}{$\begin{array}{c}{[1]<->[2]: 0.28(0.65-2.33), \chi^{2}=0.41, p=0.524[11]<->[12]:} \\
1.37(0.61-3.09), \chi^{2}=0.58, p=0.447[11]<->[22]: \\
1.16(0.24-5.57), \chi^{2}=0.04, p=0.851[11]<->[12+22]: \\
1.33(0.62-2.87), \chi^{2}=0.54, p=0.461\end{array}$} \\
\hline & $T$ & $43 / 22.0 \pm 2.8$ & $17 / 20.0 \pm 4.2$ & $26 / 23.0 \pm 3.8$ & \\
\hline & $\mathrm{CC}$ & $73 / 62.9$ & $34 / 66.7$ & $39 / 60.0$ & \\
\hline & TC & $36 / 31.0$ & $14 / 27.5$ & $22 / 33.9$ & \\
\hline & $\pi$ & $7 / 6.0$ & $3 / 5.9$ & $4 / 6.2$ & \\
\hline \multirow{5}{*}{ 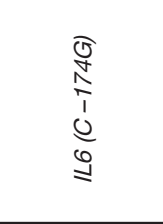 } & C & $79 / 45.0 \pm 3.4$ & $31 / 40.0 \pm 5.2$ & $48 / 48.0 \pm 4.3$ & \multirow{5}{*}{$\begin{array}{c}{[1]<->[2]: 0.72(0.42-1.21), \chi^{2}=1.58, p=0.209[11]<->[12]:} \\
1.05(0.40-2.76), \chi^{2}=0.01 p=0.925[11]<->[22]: \\
0.57(0.20-1.59), \chi^{2}=1.18, p=0.277[11]<->[12+22]: \\
0.81(0.33-2.00), \chi^{2}=0.20, p=0.652\end{array}$} \\
\hline & G & $91 / 55.0 \pm 3.4$ & $41 / 60.0 \pm 5.2$ & $50 / 52.0 \pm 4.3$ & \\
\hline & $\mathrm{CC}$ & $25 / 21.5$ & $10 / 19.6$ & $15 / 23.1$ & \\
\hline & CG & $54 / 46.5$ & $21 / 41.2$ & $33 / 50.8$ & \\
\hline & GG & $37 / 31.9$ & $20 / 39.2$ & $17 / 26.2$ & \\
\hline \multirow{5}{*}{ 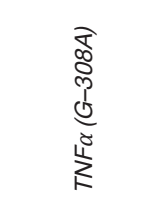 } & G & $32 / 18.0 \pm 2.9$ & \multirow{5}{*}{\multicolumn{3}{|c|}{$\begin{array}{l}\text { Does not conform to the Hardy-Weinberg equilibrium } \\
\qquad(p=0.0001)\end{array}$}} \\
\hline & A & $106 / 92.0 \pm 2.9$ & & & \\
\hline & GG & $10 / 8.6$ & & & \\
\hline & GA & $22 / 19.0$ & & & \\
\hline & AA & $84 / 72.4$ & & & \\
\hline
\end{tabular}

Note: ARI — acute respiratory infections; * - statistically significant differences in the allele frequency at the given locus $(p<0.05)$; ${ }^{*}$ - statistically significant associations with increased risk of respiratory infections.

important stage because if observed frequencies are consistent with those predicted by the Hardy-Weinberg equation, it means that patient selection for a genetic study is adequate. The frequencies of 5 out of 6 analyzed polymorphisms was consistent with the Hardy-Weinberg equilibrium, except for $T N F \alpha$ (G-308A). For the G-308A polymorphism of the TNF $\alpha$ gene, the frequency of the heterozygous genotype observed in the general sample was different from the predicted frequency. This could be explained by the insufficient number of observations and the character of allele distribution for this locus in the studied group. Therefore, TNF $\alpha$ (G-308A) was excluded from further analysis.

The analysis of allele and genotype frequencies of $I L 1 \beta$ and IL6 revealed that the general sample was dominated by the carriers of the T-31, G-1473 and C-3953 polymorphisms of the IL1 $\beta$ gene and the G-174 polymorphism of the IL 6 genes. The distribution of $I L 1 \beta(T-511 C)$ alleles was relatively even. The pattern of allele/genotype distribution for this polymorphism was similar to that observed in the European female population
[23] and Russian females residing in Moscow [24], which may indicate the evolutionary advantage of the alleles that determine high levels of proinflammatory cytokines in the Caucasian population.

The subsequent analysis of the associations between predisposition to frequent $A R I$ and the carriership of the studied alleles at the polymorphic loci of the genes encoding proinflammatory cytokines demonstrated that the presence of the $C-31$ and $C-511$ alleles in the $I L 1 \beta$ gene significantly increased the risk of recurrent respiratory infections (2- to 3-fold), especially in the homozygous patients. In the girls with recurrent respiratory tract infections, the $G$ allele in locus 174 of the $I L-6$ gene was 1.5 times rarer $(p>0.05)$. The discovered association between the polymorphic $C-31$ and $C-511$ alleles of the $I L 1 \beta$ gene and frequent respiratory infections is consistent with the literature: $I L-1 \beta$ plays a central role in the generation and regulation of immune response against infection; carriership of polymorphic variants at positions $31 T$ and $511 T$ in most cases leads to an increase in the production of this cytokine in vivo 
and in vitro in comparison with $C$ alleles, whose carriership increases the severity and frequency of respiratory infections in children and adults [25-27].

For some European populations, $I L 1 \beta(T-31 C)$ is in $100 \%$ linkage disequilibrium with $I L 1 \beta$ (T-511C) [28], which seems to explain similar risks associated with this pair of SNPs.

The fact that only 2 SNPs of the IL $1 \beta$ gene were significantly associated with frequent respiratory infections suggests the need for identifying the subgroups with high prevalence of bacterial/viral infections, the presence/absence of allergies, etc. in the general sample of children predisposed to recurrent ARI, as well as the need for a larger patient sample. At the same time, the cytokine system is a polymorphic, highly reliable pleiotropic regulatory network of mediators whose biological effects are exerted in a cascade manner, are very diverse and sometimes excessive [29]. Therefore, a decrease in the expression of one or several cytokine genes and the resulting low production of the peptide mediator will not always be accompanied by a pronounced pathology. This means that research into the effects of polymorphisms in the cytokine genes should not be limited to the analysis of carriership of individual polymorphic variants occurring in a few cytokine genes. It is important to consider linked inheritance, mutual effects, interactions with receptors and other factors affecting the cytokine status in health and pathology.

\section{CONCLUSIONS}

1. The studied group of 7 to 17 -year old girls residing in Samara was dominated by the carriers of the alleles T-31, G-1473, $C$-3953 in the $I L 1 \beta$ gene and the G-174 allele in the IL 6 gene. 2. The presence of the alleles $C-31$ and $C-511$ in the $I L 1 \beta$ gene was associated with the increased risk of recurrent respiratory infections. 3. The established association between the studied gene variants and respiratory infections dictates the need for further research into the functional polymorphisms of cytokine genes aiming at developing new diagnostic approaches, prevention measures and personalized therapies. 4. The analysis of carriership of individual polymorphic gene variants in the cytokine system is not enough for the comprehensive assessment of individual immunogenetic features and the search for genetic markers for prediction, prevention and personalized treatment; it is important to account for linked inheritance, mutual effects, interactions with receptors and other factors affecting the cytokine status in health and pathology.

\section{References}

1. Sepiashvili RI, Slavyanskaya TA. Strategiya i taktika kompleksnoy immunoreabilitatsii bol'nykh s zabolevaniyami immunnoy sistemy. Allergologiya i immunologiya. 2015; 16 (1): 51-7. Russian.

2. Ketlinskiy SA, Simbirtsev AS. TSitokiny. SPb.: Foliant, 2008; 552 s. Russian.

3. Gulomov ZS, Simbirtsev AS, Yanov YuK, Varyushina EA, Tyrnova EV. Rol' tsitokinov pri lechenii ostrykh i khronicheskikh zabolevaniy verkhnikh dykhatel'nykh putey (Obzor literatury). Rossiyskaya otorinolaringologiya. 2008; 37 (6): 200-5. Russian.

4. Prilepskaya VN, Letunovskaya AB, Donnikov AE. Mikrobiotsenoz vlagalishcha i polimorfizm genov tsitokinov kak marker zdorov'ya zhenshchiny (obzor literatury). Ginekologiya. 2015; 17 (2): 4-13.

5. Bodiyenkova GM, Titova ZhV. Rol' polimorfizma i ekspressii otdel'nykh genov tsitokinov $v$ formirovanii patologii (Obzor). Uspekhi sovremennogo estestvoznaniya. 2015; (1): 616-20. Russian.

6. Nesterova IV, Kovaleva SV, Kleshchenko El, Shinkareva ON, Malinovskaya W, Vyzhlova EN. Retrospektivnyy analiz klinicheskoy effektivnosti korotkikh kursov interferonov $v$ lechenii ORVI u immunokomprometirovannykh chasto i dlitel'no boleyushchikh detey. Pediatriya. ZHurnal imeni G.N. Speranskogo. 2014; 93 (2): 62-7. DOI:10.24110/0031-403X-2014-93-2-62-67. Russian.

7. Shevchenko AV, Golovanova OV, Konenkov VI. Osobennosti polimorfizma promotornykh regionov genov tsitokinov IL1, IL4, IL5, IL6, IL10 i TNF- $\alpha$ u evropeoidnogo naseleniya Zapadnoy Sibiri. Immunologiya. 2010; (4): 176-81. Russian.

8. Abramov DD, Kofiadi IA, Khaitov MR, Sergeyev IV, Trofimov DYu, Gudima GO, i dr. Osobennosti polimorfizma genov, reguliruyushchikh razlichnyye komponenty immunnogo otveta, $v$ russkoy populyatsii. Rossiyskiy allergologicheskiy zhurnal. 2012; (6): 72-5. Russian.

9. Prokofyev VF, Shevchenko AV, Golovanova OV, Zonova EV, Korolev MA, Leonova YuB. Kompleksnyy analiz polimorfizma $\checkmark$ promotornykh uchastkakh genov tsitokinov IL-1B T-31C, IL-6 G-174C, TNFA G-238A, TNFA G-308A, TNFA C-863A, IL-4 C-590T i IL-10 C-592 $\alpha$ v prognoze effekta ot lecheniya revmatoidnogo artrita. Meditsinskaya immunologiya. 2010; (4): 361-74. Russian.

10. Smolnikova MV, Smirnova SV, Tyutina OS. Polimorfizm genov tsitokinov pri atopicheskoy bronkhial'noy astme. Sibirskoye meditsinskoye obozreniye. 2013; (2): 63-69. Russian.
11. Kutikhin AG, Brusina EB, Volkov AN, Yuzhalin AE, Zhivotovskiy AS. Correlation between genetic polymorphisms within IL-1B and TLR4 genes and cancer risk in a Russian population: a casecontrol study. Tumor Biol. 2014; 35 (5): 4821-30.

12. Zhu Q, Sun J, Chen Y. Preterm birth and single nucleotide polymorphisms in cytokine genes. Transl Pediatr. 2014; 3 (2): 120-134. DOI: 10.3978/j.issn.2224-4336.2014.03.02.

13. Abramova NA, Savenkova MS. Rol' sotsial'nykh i ekologicheskikh faktorov $v$ formirovanii gruppy chasto boleyushchikh detey $v$ sotsial'no blagopoluchnykh sem'yakh g. Moskvy. Detskiye infektsii. 2013; (4): 52-7. Russian.

14. Yulish El, Yaroshenko SyA. Chasto boleyushchiye deti i taktika pediatra. Zdorov'ye rebenka. 2013; 49 (6): 70-6. Russian.

15. Khlynina YuO, Kramar LV. Sovremennyye podkhody k profilaktike i lecheniyu ORZ u chasto boleyushchikh detey. Lekarstvennyy vestnik. 2015; 59 (4): 40-5. Russian.

16. Marsh SG, Albert ED, Bodmer WF, Bontrop RE, Dupont B, Erlich HA, et al. An update to HLA nomenclature, 2010. 2010; 45 (5): 846-8.

17. Available from: http://ihg.gsf.de/cgi-bin/hw/hwa1.pl.

18. Levina AS, Babachenko IV, Skripchenko NV, Imyanitov EN. Etiologicheskaya struktura zabolevaniy u chasto boleyushchikh detey v zavisimosti ot vozrasta. Rossiyskiy vestnik perinatologii i pediatrii. 2017; 62 (2): 72-7. Russian.

19. Esposito S, Bianchini S, Bosis S, Tagliabue C, Coro I, Argentiero A, Principi N. A randomized, placebo-controlled, double-blinded, single-centre, phase IV trial to assess the efficacy and safety of OM-85 in children suffering from recurrent respiratory tract infections. J Transl Med. 2019 Aug 23; 17 (1): 284. DOI: 10.1186/ s12967-019-2040-y. PMID: 31443716 Free PMC Article.

20. Simbirtsev AS, Totolyan AA. Tsitokiny v laboratornoy diagnostike. Infektsionnyye bolezni: novosti, mneniya, obucheniye. 2015; (2): 82-98. Russian.

21. Kazakova AV, Uvarova EV, Limareva LV, Trupakova AA, Mishina Al. Sposob prognozirovaniya bakterial'nogo vul'vovaginita u devochek $v$ zavisimosti ot stadii polovogo razvitiya soglasno shkale Tannera. Vestnik RGMU. 2019; (5): 116-22. DOI: 10.24075/vrgmu.2019.070. Russian.

22. Khazim K, Azulay EE, Kristal B, Cohen I. Interleukin 1 gene polymorphism and susceptibility to disease. Immunol Rev. 2018 Jan; 281 (1): 40-56. DOI: 10.1111/imr.12620.

23. Available from: http://www.ensembl.org/index.html. 
24. Kofiadi IA, Kadochnikova VV, Abramov DD, Goncharova EV, Donnikov AE, Trofimov DYu, i dr. Chastota vstrechayemost 100 klinicheski znachimykh odnonukleotidnykh polimorfizmov u zdorovykh predstaviteley russkoy populyatsii. Fiziologiya i patologiya immunnoy sistemy. 2011; (2): 3-10. Russian.

25. Terskova NV, Shnayder NA, Vakhrushev SG, Ikonnikova EV, Pilyugina MS. Rol' polimorfizma gena interleykina- $1 \beta \vee$ razvitii vospaleniya glotochnoy mindaliny. Ros. otorinolaringologiya. 2010; (6): 87-93. Russian.

26. Chen H, Wilkins LM, Aziz N. Single nucleotide polymorphisms in the human interleukin-1B gene affect transcription according to haplotype context. Hum Mol Genet. 2006; (15): 519-29.

27. Todorović MM, Zvrko EZ. Immunoregulatory cytokines and chronic tonsillitis. Bosn J Basic Med Sci. 2013; 13 (4): 230-6. PMID: 24289758.

28. Gromova AYu, Simbirtseva AS. Polimorfizm genov semeystva IL-1 cheloveka. Tsitokiny i vospaleniye. 2005; (2): 3-12. Russian.

29. Tsygan VN, Ivanov AM, Kamilova TA, Protasov OV, Artyushkin SA. Geneticheskiy polimorfizm tsitokinov. Vestnik Rossiyskoy voyenno-meditsinskoy akademii. 2010; 30 (2): 211-9. Russian.

\section{Литература}

1. Сепиашвили Р. И., Славянская Т. А. Стратегия и тактика комплексной иммунореабилитации больных с заболеваниями иммунной системы. Аллергология и иммунология. 2015; 16 (1): 51-7.

2. Кетлинский С. А., Симбирцев А. С. Цитокины. СПб.: Фолиант, 2008; 552 c

3. Гуломов 3. С., Симбирцев А. С., Янов Ю. К., Варюшина Е. А., Тырнова Е. В. Роль цитокинов при лечении острых и хронических заболеваний верхних дыхательных путей (Обзор литературы). Российская оториноларингология. 2008; 37 (6): 200-05

4. Прилепская В. Н., Летуновская А. Б., Донников А. Е. Микробиоценоз влагалища и полиморфизм генов цитокинов как маркер здоровья женщины (обзор литературы). Гинекология. 2015; 17 (2): 4-13.

5. Бодиенкова Г. М., Титова Ж. В. Роль полиморфизма и экспрессии отдельных генов цитокинов в формировании патологии (Обзор). Успехи современного естествознания. 2015; (1): 616-20.

6. Нестерова И. В., Ковалева С. В., Клещенко Е. И., Шинкарева О. Н., Малиновская В. В., Выжлова Е. Н. Ретроспективный анализ клинической эффективности коротких курсов интерферонов в лечении ОРВИ у иммунокомпрометированных часто и длительно болеющих детей. Педиатрия. Журнал имени Г. Н. Сперанского. 2014; 93 (2): 62-7. DOl:10.24110/0031-403X-2014-93-2-62-67

7. Шевченко А. В., Голованова О. В., Коненков В. И. Особенности полиморфизма промоторных регионов генов цитокинов IL1, IL4, IL5, IL6, IL10 и TNF- $\alpha$ у европеоидного населения Западной Сибири. Иммунология. 2010; (4): 176-81.

8. Абрамов Д. Д., Косиади И. А., Хаитов М. Р., Сергеев И. В., Трофимов Д. Ю., Гудима Г. О. и др. Особенности полиморфизма генов, регулирующих различные компоненты иммунного ответа, в русской популяции. Российский аллергологический журнал. 2012; (6): 72-5.

9. Прокофьев В. Ф., Шевченко А. В., Голованова О. В., Зонова Е. В., Королев М. А., Леонова Ю. Б. Комплексный анализ полиморфизма в промоторных участках генов цитокинов IL-1B T-31C, IL-6 G-174C, TNFA G-238A, TNFA G-308A, TNFA C-863A, IL-4 C-590T и IL-10 C-592 $\alpha$ в прогнозе эффекта от лечения ревматоидного артрита. Медицинская иммунология. 2010; (4): 361-74

10. Смольникова М. В., Смирнова С. В., Тютина О. С. Полиморфизм генов цитокинов при атопической бронхиальной астме. Сибирское медицинское обозрение. 2013; (2) 63-9.

11. Kutikhin AG, Brusina EB, Volkov AN, Yuzhalin AE, Zhivotovskiy AS. Correlation between genetic polymorphisms within $\mathrm{IL}-1 \mathrm{~B}$ and TLR4 genes and cancer risk in a Russian population: a casecontrol study. Tumor Biol. 2014; 35 (5): 4821-30.

12. Zhu Q, Sun J, Chen Y. Preterm birth and single nucleotide polymorphisms in cytokine genes. Transl Pediatr. 2014; 3 (2): 120-34. DOI: 10.3978/j.issn.2224-4336.2014.03.02.

13. Абрамова Н. А., Савенкова М. С. Роль социальных и экологических факторов в формировании группы часто

болеющих детей в социально благополучных семьях г. Москвы. Детские инфекции. 2013; (4): 52-7.

14. Юлиш Е. И., Ярошенко С. Я. Часто болеющие дети и тактика педиатра. Здоровье ребенка. 2013; 49 (6): 70-6.

15. Хлынина Ю. О., Крамарь Л. В. Современные подходы к профилактике и лечению ОРЗ у часто болеющих детей. Лекарственный вестник. 2015; 59 (4): 40-5.

16. Marsh SG, Albert ED, Bodmer WF, Bontrop RE, Dupont B, Erlich HA et al. An update to HLA nomenclature, 2010. 2010; 45 (5): 846-8.

17. Доступно по ссылке: http://ing.gsf.de/cgi-bin/hw/hwa1.pl.

18. Левина А. С., Бабаченко И. В., Скрипченко Н. В., Имянитов Е. Н. Этиологическая структура заболеваний у часто болеющих детей в зависимости от возраста. Российский вестник перинатологии и педиатрии. 2017; 62 (2): 72-7.

19. Esposito S, Bianchini S, Bosis S, Tagliabue C, Coro I, Argentiero A et al. A randomized, placebo-controlled, double-blinded, singlecentre, phase IV trial to assess the efficacy and safety of OM-85 in children suffering from recurrent respiratory tract infections. J Transl Med. 2019 Aug 23; 17 (1): 284. DOl: 10.1186/s12967019-2040-y. PMID: 31443716 Free PMC Article.

20. Симбирцев А. С., Тотолян А. А. Цитокины в лабораторной диагностике. Инфекционные болезни: новости, мнения, обучение. 2015; (2): 82-98.

21. Казакова А. В., Уварова Е. В., Лимарева Л. В., Трупакова А. А. Мишина А. И. Способ прогнозирования бактериального вульвовагинита у девочек в зависимости от стадии полового развития согласно шкале Таннера. Вестник РГМУ. 2019; (5): 116-22. DOI: 10.24075/vrgmu.2019.070.

22. Khazim K, Azulay EE, Kristal B, Cohen I. Interleukin 1 gene polymorphism and susceptibility to disease. Immunol Rev. 2018 Jan; 281 (1): 40-56. DOl: 10.1111/imr.12620.

23. Доступно по ссылке: http://www.ensembl.org/index.html.

24. Кофиади И. А., Кадочникова В. В., Абрамов Д. Д., Гончарова Е. В., Донников А. Е., Трофимов Д. Ю. Частота встречаемости 100 клинически значимых однонуклеотидных полиморфизмов у здоровых представителей русской популяции. Физиология и патология иммунной системы. 2011; (2): 3-10.

25. Терскова Н. В., Шнайдер Н. А., Вахрушев С. Г., Иконникова Е. В., Пилюгина М. С. Роль полиморфизма гена интерлейкина$1 \beta$ в развитии воспаления глоточной миндалины. Рос. оториноларингология. 2010; (6): 87-93.

26. Chen H, Wilkins LM, Aziz N. Single nucleotide polymorphisms in the human interleukin-1B gene affect transcription according to haplotype context. Hum Mol. Genet. 2006; (15): 519-29.

27. Todorović MM, Zvrko EZ. Immunoregulatory cytokines and chronic tonsillitis. Bosn J Basic Med Sci. 2013; 13 (4): 230-6. PMID: 24289758.

28. Громова А. Ю., Симбирцева А. С. Полиморфизм генов семейства IL1 человека. Цитокины и воспаление. 2005; (2): 3-12.

29. Цыган В. Н, Иванов А. М., Камилова Т. А., Протасов О. В., Артюшкин С. А. Генетический полиморфизм цитокинов. Вестник Российской военно-медицинской академии. 2010; 30 (2): 211-9. 